\title{
Monetary policy as a source of risk in international business financings and investments
}

\author{
Cristian PAUN \\ The Bucharest University of Economic Studies, Bucharest, Romania \\ cristian.paun@rei.ase.ro
}

\begin{abstract}
This paper aims at explaining the volatility of two main macroeconomic variables (interest rate and exchange rate) that impact the cost of international capital and, consequently, the international financing decision. Firstly, the main economic theories are called to illustrate the relevant determinants of these variables from the perspective of demand and supply of capital sides. The state intervention through monetary policy is introduced to emphasize the alteration of these prices (the price of capital, the price of foreign currencies). The paper is presenting the role of these prices in international financing decision (based on the theoretical model used to estimate cost of international capital), their impact on the foreign direct investment decision and on the international portfolio investment decision. Finally, the paper describe the economic consequences of the monetary public intervention on the financing and investment decision in direct connection with the business cycle theory. The paper associates the monetary policy to the business cycles. The paper comments the unsound solutions proposed against the economic crises and that continued to harm negatively these prices generating the seeds for next international economic recession. The paper is a theoretical one, containing some very interesting research hypothesis and opening the paths for presumable further empirical researches.
\end{abstract}

Keywords: international financing, cost of international capital, international financing decision, interest rate, exchange rate, monetary policy.

\section{Introduction}

The capital is one of the most important production factor. In the absence of this factor, all the others (natural resources, labor etc.) remain unused or inefficiently used. This production factor is vital for any combination of productive factors, significantly contributing to the economic development of nations. The nature of this source is very clear: the savings of present consumptions. The occurrence of capital in a different way than saving present consumptions is not natural (you cannot create capital out of nothing). The capital cannot be printed or hand-made. Capital could be the result of labor but is more than that: it is saved result of a specific labor. The price of capital is reflecting the time preference of the people postponing their consumption for the future moment and of the people interested to consume more today than in the future. This price is inflation adjusted, risk adjusted (systemic risk, default risk) and liquidity adjusted. Therefore, the zero interest rate or negative interest rate is out of any economic logic. The financing and investment decision is based on the analysis of this key economic variable that is interest rate. The pricing of financial assets is based on this key economic variable. An additional variable - exchange rate - is introduced in this financing and investment mechanism when this capital is transferred from international financial markets. Unfortunately, today both prices are highly altered by the intervention of the state and by a specific public policy that is monetary policy. When we decide about investing or financing a business with an international capital, we can be a victim of this state intervention that could generate huge errors and business costs (including bankruptcy of real businesses). Consequently, the business cycles are higher and more frequent than in the past (due to these unforeseen errors produced by the state monetary intervention). This paper is providing an analysis on the mechanism for 
financing a business by accessing international financial markets and is presenting the most sensitive aspects in this case that are connected to the state intervention and that is seen to be the clear source of systemic risk for such businesses or investments.

\section{The international financing and investment decisions}

International capital still remains a reliable source of financing for economic PICBE|661 development of emerging and transition markets. The liberalization of capital account, the development of financial intermediaries, the higher integration of capital markets and the business globalization contributed a lot to the growth of the volume of international flows in the latest decades. The global foreign direct investments volume reached 1792 billion dollars in 2015, mostly due to cross-border M\&A initiated from developed countries; developing countries and transition economies attracted $45 \%$ of this volume; developing Asia and Europe remain the most important attractor for such investments with more than $50 \%$ of this volume (UNCTAD, World Investment Report, 2016). The internationalization of capital flows improved the risk sharing and ensured a better allocation of it among various countries and business sectors (Cœuré, 2016).

The theoretical model of selecting among various international financing sources is based on two main criteria: net present value (NPV) and internal rate of cost (IRC) that is determined by equalizing NPV of a financing source with zero (Madura, 2014). When we want to decide between two or more financing alternatives, we estimate NPV and IRC and we choose for maximum NPV and minimum IRC. Normally both criteria should return the same solution. If not, there could be a problem with initial conditions (different financing volume) (Eun and Resnick, 2014). The discount rate used to discount the annuities associated with a financing scheme is expected average interest rate covering the entire financing period (the equity financing is more sensitive because it has no fixed maturity associated to it) (Shapiro, 2013). In international financings, different discount rates are used for different currencies denominating annuities: a discount rate for euro denominated annuities is different than the discount rate for dollars denominated annuities (discount rate used to estimate net present value of such financing schemes are reflecting an expectation in terms of interest rate for different currencies). IRC is more difficult to be estimated (Madura, 2014).

Table 1. International financing decision criteria

\begin{tabular}{|c|c|}
\hline Net present value & Internal rate of cost \\
\hline $\mathrm{NPV}_{\text {financing }}=$ Initial credit $-\sum_{\mathrm{n}=1}^{\text {Maturity }} \frac{\text { Annuity }}{(1+\mathrm{k})^{\mathrm{n}}}$ & IRC $=\mathrm{k}^{*} \quad<=>\mathrm{NPV}_{\text {financing }}=0$ \\
\hline $\begin{array}{c}\text { The best financing alternative is that providing } \\
\text { the maximum value for NPV }\end{array}$ & $\begin{array}{c}\text { The best financing } \\
\text { providing the minimum valternative is that }\end{array}$ \\
\hline
\end{tabular}
Source: Paun, 2012.

When we estimate NPV for such international financings and when we want to compare between them, we should deal with a specific problem: their denomination in different currencies. In this case, several methods are proposed (Paun, 2012): (i) to use different discount rates for each currency and to transform each $\mathrm{NPV}_{\text {financing }}$ in the same currency using current exchange rate; (ii) to select one representative currency (normally the local currency) and to use a predicted exchange rate to transform all annuities in the same currency and to discount them with the discount rate for selected representative currency and (iii) to estimate a discount rate for each currency based on the projections for interest rates and to convert each NPV financing in the same currency by using an average exchange rate based on the projections for exchange rates. In case of 
IRC it is recommended to denominate all financings in one representative currency by using projected exchange rates covering all financing period of time.

The best measure for the cost of capital is that internal rate of cost (IRC) obtained from $\mathrm{NPV}_{\text {financing }}=0$. The first conclusion is the following: the financing decision is sensitive to the estimations of interest rate and exchange rate (NPV criterion) and, finally, the cost of capital is sensitive to exchange rate. Both macroeconomic variables are highly influencing the cost of international capital.

Table 2. Foreign direct investment decision criteria

\begin{tabular}{|c|c|c|}
\hline Criterion & Formula & Condition for decision \\
\hline $\begin{array}{c}\text { Net present } \\
\text { value of } \\
\text { investment }\end{array}$ & $\mathrm{NPV}_{\mathrm{inv}}=$ Initial investment $-\sum_{\mathrm{n}=1}^{\text {Lifetime }} \frac{\text { Net cash flows }}{(1+\mathrm{k})^{\mathrm{n}}}+\frac{\text { Residual value }}{(1+\mathrm{k})^{\text {Lifetime }}}$ & $\begin{array}{l}\text { Maximum net present value; positive } \\
\text { value; discount rate used is the } \\
\text { estimated cost of capital. }\end{array}$ \\
\hline $\begin{array}{l}\text { Internal rate of } \\
\text { return }\end{array}$ & $\mathrm{IRC}=\mathrm{k}^{*} \quad<=>\mathrm{NPV}_{\text {investment }}=0$ & $\begin{array}{l}\text { Maximum internal rate of return; } \\
\text { higher than the cost of capital. }\end{array}$ \\
\hline $\begin{array}{l}\text { Profitability } \\
\quad \text { ratio }\end{array}$ & $\mathrm{PR}=\frac{\sum_{\mathrm{n}=1}^{\text {Lifetime }} \frac{\text { Net cash flows }}{(1+\mathrm{k})^{\mathrm{n}}}+\frac{\text { Residual value }}{(1+\mathrm{k})^{\text {Lifetime }}}}{\text { Initial investment }}$ & $\begin{array}{l}\text { The value of PR should be higher } \\
\text { than } 1 \text {. For discounting of cash flows } \\
\text { we use the estimated cost of capital. }\end{array}$ \\
\hline Recovery time & $R T<=>$ Initial investment $=\sum_{\mathrm{n}=1}^{\mathrm{Lifetime}} \frac{\text { Net cash flows }}{(1+\mathrm{k})^{\mathrm{n}}}$ & $\begin{array}{l}\text { The recovery time for an investment } \\
\text { project should be lower than the } \\
\text { lifetime for investment's fixed assets. } \\
\text { For discounting of cash flows we use } \\
\text { the estimated cost of capital. }\end{array}$ \\
\hline
\end{tabular}

Source: Paun, 2012.

The theoretical model of investing capital in international projects is based on four basic criteria (see Table 2): net present value (NPV investment) associated to that investment based on projected net cash flows and residual value of that investment; internal rate of return (IRR) that is estimated from equation $N P V_{\text {investment }}=0$; profitability ratio that compares net cash flows (including residual value) with initial investment and recovery time of that investment calculated by cumulating discounted net cash flows until the moment when initial investment is full recovered (Bekaert and Hodrick, 2014). The discount of net cash flows is based on previous cost of capital estimation (that is sensitive to interest rate and exchange rate projection). When various international projects are compared, the net cash flows should be denominated in the same currency. When the project generates inflows and outflows denominated in various currencies, a projection of exchange rate is used to be able to estimate net cash flows.

The second conclusion could be drawn from this theoretical model used to select among various international investment projects: the investment decision is highly sensitive to interest rate and exchange rate estimates. Any mistake in the selection of financing alternatives and any mistake in the estimation of the cost of capital will impact the decision to invest capital in a specific international project.

The decision to buy or to sell financial assets that are internationally traded is based on pricing of such assets and on the estimated return of them (Sounders and Cornett, 2014). In the theoretical model of portfolio investments that are internationally diversified (see Table 3), the price of financial assets is depending on the future cash flows generated by such asset (including principal, interest or coupon rate, dividends etc.). These cash flows will be discounted with an expected interest rate. Moreover, if the assets are denominated in different currencies, the estimations suppose an exchange rate projection. This price is directly connected with the interest rate: if the interest rate drops, the price of financial assets is increasing (Dobbs et al., 2015). 
Table 3. International portfolio investment decision criteria

\begin{tabular}{|c|c|c|}
\hline Criterion & Formula & $\begin{array}{c}\text { Condition for decision } \\
\text { The net cash flows include principal } \\
\text { payoffs, coupon or interest rate } \\
\text { payments, dividend payments. The } \\
\text { discount rate is expected return. } \\
\text { The relationship between the } \\
\text { changes in the level of this price and } \\
\text { interest rate is described by: } \\
\begin{array}{c}\text { Pp } \\
\mathrm{p}_{0}\end{array} \\
\text { financial assets } \text { Duration } \times \frac{\Delta \text { interest }}{\text { interest }}\end{array}$ \\
$\begin{array}{c}\text { The investor are searching for } \\
\text { financial assets with a price that is } \\
\text { increasing for a long (buyer) position } \\
\text { and a price that is decreasing for a } \\
\text { short (seller) position. }\end{array}$ \\
\hline $\begin{array}{c}\text { Expected } \\
\text { return of } \\
\text { financial assets }\end{array}$
\end{tabular}

Source: Paun, 2012.

The return of financial assets is calculated by looking to the price differential between initial moment (when capital is invested) and final moment (when financial assets are sold on the financial markets). Dividends or other additional payoffs are adjusting this return. The conclusion is clear: due to the fact that the price of financial assets is influenced by interest rate and exchange rate, the return is also sensitive to both of them.

\section{The volatility of interest rate an exchange rate in case of international financial markets}

The presented theoretical models indicated that the decision to access international capital to finance the development of a business, the decision to invest money abroad to build a production facility (as a foreign direct investment) or the decision to diversify internationally your portfolio of financial assets are directly linked to two key macroeconomic variables: interest rate and exchange rate.

In the case of interest rate, we can identify the following potential drivers derived from demand \& supply with capital approach (Mishkin and Eakins, 2014; Mishkin, 2014):

- Wealth (income): if the wealth of people is increasing, more resources will be saved and interest rates will drop (negative relationship);

- Anticipated inflation: if the prices are expected to be higher in the future, the people will save less (preferring to consume now) and interest rates will increase. On the other hand, if the entrepreneurs will expect a higher inflation (lower purchasing power of existing money), they will ask for more debts and, therefore, the interest rate will increase (positive relationship; Fisher effect);

- Liquidity of financial assets: if the liquidity will decrease (the investors will have more difficulties / costs in the case of cash redemption of financial assets), the interest to save and invest capital will decrease and the interest rates will increase (negative relationship);

- Return of financial investments: if the investments in financial assets will generate more return compared with other alternatives (real assets for instance), the interest for saving and investment will increase and the interest rate will drop (negative relationship); 
- Risk associated to financial investments: if the risk is higher, the savings and investments will drop and the interest rate will increase (positive relationship);

- Public deficits: if the public deficits will increase, the state will be more active on financial markets by issuing bonds or asking for credits and this higher presence will increase the level of interest rate(positive relationship);

- Expected economic growth: when economy is expected to grow (after recession), the entrepreneurs will ask for more capital to invest it in productive processes that will ensure a higher market share in the future, the demand for capital will increase and the interest rate will increase (positive relationship).

Considering all these factors derived from demand and supply side of capital, we can conclude that, in case of recession (higher risks, higher expected inflation, lower incomes, lower liquidity, higher deficits etc.), the interest rate is submitted to increase. The statistical data provides an opposite evolution for interest rates at international level: real global bond yields were negative in 2016 (around -3\%), the monetary policy interest rate declined to around $1 \%$ in United States, around $0.4 \%$ in United Kingdom and is negative in Euro Area (around - 0.1\%) and Japan (around -0.25\%). Data for monetary policy interest rate are from September 2016 (Source: IMF Global Financial Stability Report, Oct. 2016, p. 7). This continued drop in the level of interest rates fueled the continued growth of debt (especially public debt in the latest years): the public debt to GDP reached $104 \%$ in 2014 , compared with private debt that remained stable to $156 \%$ of GDP in 2014, compared with $158 \%$ of GDP in 2007). The continued fall of interest rate reflect the fact that the price (cost) of capital today is not based on demand \& supply of capital fundamentals explained by economic theory. In fact, this price today is out of market and is significantly altered by monetary policy of the central banks. We are completely blinded if we want to forecast this price by using economic theory and to introduce this expected value in our decision to finance, to invest or to by financial securities.

The case of exchange rate is the same. The main drivers that could explain the volatility of this macroeconomic variable are the following (Copeland, 2014):

- Commercial balance of foreign trade: if exports are increasing, the supply with foreign currency will increase and the local currency will appreciate; if the imports will increase, the demand for foreign currency will increase and the local currency will depreciate;

- International investment balance: when more foreign investors are interested to invest their capital in a specific country, the supply with foreign currency will increase and the local currency will appreciate; if local companies are interested to invest abroad more, the demand for foreign currency will increase and the local currency will depreciate;

- Incomes balance: if the outflows of incomes (from labor, capital, real assets etc.) are higher than the inflows, the local currency will depreciate. The balance of remittances or the balance of dividends generated by international investments are relevant in this case;

- Saving behavior: if local savers will prefer foreign currency to denominate their savings instead of local currency, the depreciation of local currency will occur. 
Specific macroeconomic variables are relevant to explain the dynamic of exchange rate: relative inflation (purchasing power parity theory) - the depreciation of a local currency will be present if the prices on local market will increase higher than the prices of foreign markets; relative broad money growth (monetary approach) - if the quantity of local currency will increase faster than foreign currencies, the depreciation will be present; relative interest rate - if real interest rate is higher than abroad, the local currency will appreciate its value.

Unfortunately, this price is significant altered today by monetary policy too. First of all, because there are not so many countries applying a free floating currency regime: only 29 countries out of 191 countries used this option for their currency exchange policy; the number of countries decreased from 39.9\% of them in 2008 to 34\% in 2014 . 9 of these countries are applying an inflation targeting framework (IMF Annual Report on Exchange Arrangements and Exchange Restrictions, 2014, pp. 6-8). Even in this case, the exchange rate is improperly to be considered free from any intervention due to the fact that this countries are using fiat-money (central banks are free to issue as many currency as they want, central banks have monopolistic position in the money production sharing this position with commercial banks due to fractional reserves system). When somebody can artificially produce any quantity of local currency is "needed", without any objective criterion there, the free floating exchange rate regime is very problematic. Most of the countries are applying administrated float of their exchange rate. After the breakdown of Bretton Woods International Monetary System, the administration of exchange rate became more sophisticated: no separate legal tender, currency board, conventional peg, stabilized arrangement, crawl-like arrangement, crawling peg, crawling band, horizontal band etc. In all these cases, the central banks are directly intervening in the foreign exchange markets by selling or buying foreign currency from their international reserves. Additionally, these banks can control the broad local money (the quantity of local available local currency). Conclusion is again very clear: the price of foreign exchanges is significantly altered by public intervention. In fact, both prices (interest rate and exchange rate) involved in the international financing and investment decisions are altered by monetary policy of central banks.

\section{The consequences of the altered interest rates and exchange rates on international financial flows}

A closer look to the evolution of interest rates and exchange rates of the main countries and currencies indicate a constant decrease in the level of interest rate and a constant depreciation of exchange rate over past decades. The direct consequences of altering these fundamental macroeconomic variables on the financial markets and financial instruments are the following:

- The permanent artificial decrease of interest rates is artificially increasing the price of financial assets and, therefore, the returns associated to them is artificially increased. Due to this situation, investors in financial assets are gaining more than investors in real assets and real productive processes. The depreciation of local currencies are increasing more these prices and these returns.

- The net present value of international projects is artificially increased by depreciation (by influencing the net cash flows) and by artificially lowering the interest rates. 
- Internal rate of return is artificially higher than normal situation in case of altered interest rates and exchange rates.

- The weighted average cost of international capital is artificially decreased by artificially lowering the interest rates. However, the artificial depreciation of local currencies could artificially increase the cost of capital;

- The investments are artificially faster to be recovered (the time needed to PICBE |666 recover initial investment is artificially shortened by lower interest rates and by depreciation of local currencies);

- The access to financial markets and financial resources is increased. The lowering of interest rates induces a sensation of higher accessibility of capital.

Taking into consideration all these direct effects, we can state about some other derived consequences:

- The difficulty to decide about optimal financing plan for a business (including international financial markets);

- The investors cannot calculate / estimate properly for their allocation of resources. The failure of economic calculation will generate an investment myopia: you cannot be able to say something about any capital allocation. The capital (and other resources) will be arbitrarily allocated with significant error. The whole economy will face with a waste of resources (that are limited).

- The investors will be tempted to decide for higher - value investments: higher net present value and higher internal rate of return will alter the perception about the potential of any investment project;

- The investors will be tempted to decide for longer maturity investment projects: higher net present value and higher internal return allow a higher maturity (recovery time) for any international investment project. Longer projects became attractive for investors.

- The investors will be tempted to extend the structure of production by adding more stages to their productive process than normal: when estimations are indicating higher profitability ratio, the investors could decide to include more stages in their productive process;

- The investors could decide for extending horizontally the structure of production: if profitability is higher, supporting activities (like commercial activities are for instance) will be included in the initial investment project. Investors can, for example, be tempted to build and operate a supermarket or a deposit for their products, including commercial \& distribution activities in the initial project.

- Due to artificially increased profitability of international investment projects, the investors will be tempted to choose for more capital intensive activities instead of labor intensive activities (sectors).

The distortions of investment and financing behavior are irreversible and difficult to be corrected later. These distortions are, in fact, cumulative entrepreneurial errors that are abnormal and artificially induced by public interference in the financial sector. The economic growth is above its natural state. An additional artificial economic growth is always added by such intervention. The correction are very dramatic: bankruptcy and recession are seen to be a natural adjustment of the global economic system to its real potential, after this potential was artificially boosted by unsound (unconventional) monetary policies. Due to these distortions, the business cycles significantly changed: the time distance between economic boom and economic 
recession was significantly reduced (up to 5 years and a half in United States) and the amplitude between the peak and the bottom significantly increased also. The economies have less time to be fully recovered after recession. The increase of poverty rate, social unrests, social imbalances, the reduction of saving rate, the lack of entrepreneurs are the direct consequences of such situation.

\section{Concluding remarks}

The financing and investment decisions are significantly dependent on two key macroeconomic variables: interest rate and exchange rate (when financings and investments are denominated in foreign currencies). Today, the volatility and the level of these key prices are less explained by the determinants of them derived from economic theory (such as inflation, commercial balance, level of incomes etc.), mainly due to a massive state intervention consisting in a significant expansion of money through specific mechanisms and policies. This significant alteration of such prices is irreversible affecting the financing and investment behavior and is fueling an abnormal modification in the structure of economy (longer term investments, longer structure of production etc.). The monetary and credit expansion is recognized today as the main sources of entrepreneurial error and the main source of economic crises. Business cycles are shortened and the amplitude of economic growth and, later, recession is higher. The recovery of economy after recession is more difficult. Any prediction and economic calculus is difficult to be performed in such context and, therefore, the investment and financing decision are more and more arbitrarily generating significant waste of important resources.

This theoretical paper is a good starting point for various potential empirical tests on the main emphasized hypothesis: the alteration of interest rate and exchange rate prolonged the duration of investment projects; there could be a link between the interest rate / exchange rate and the production stages of various investment projects; the alteration of interest rate and exchange rate influenced the preference of investors for capital intensive sectors; lower interest rate and depreciation of exchange rate is destroying the economic value by validating investment projects with lower return on invested capital than the cost of capital etc.

\section{References}

Bekaert, J.G., Hodrick, R.J. (2011). International Financial Management, New Jersey, NJ: Pearson Prentice Hall.

Cœuré, B. (2016), Sustainable Globalisation: Lessons from Europe, Public Speech to the Workshop: Financial globalization and its spillovers - monetary and exchange rate policy in times of crises, European Central Bank.

Copeland, L. (2014), Exchange Rates \& International Finance, Pearson Education.

Eun, C., Resnick, B. (2014), International Financial Management, McGraw-Hill Education, $7^{\text {th }}$ Edition.

Madura, J. (2014), Financial markets and Institutions, Nelson Education.

Madura, J. (2014), International Financial Management, South-Western College Pub, $12^{\text {th }}$ Edition.

Mishkin, F. (2014), The Economics of Money, Banking and Financial Markets, Pearson Education.

Mishkin, F., Eakins, S. (2014), Financial Markets and Institutions, Pearson Education. 
Paun, C. (2012), International Financing Decision: A Managerial Perspective, Review of International Comparative Management, 13(3), 411-425.

Shapiro, A.C. (1984), Multinational Financial Management, Journal of International Business Studies.

Sounders, A., Cornett, M. (2014), Financial Markets and Institutions, The Mcgraw-Hill / Irwin Series in Finance, Insurance and Real Estate, $6^{\text {th }}$ Edition.

Risks, C. S., \& Soundness, R. F. (2008). Global Financial Stability Report. International Monetary Fund, Washington.

Dobbs, R., Lund, S., Woetzel, J., \& Mutafchieva, M. (2015). Debt and (not much) deleveraging. McKinsey Global Institute, 136.

UNCTAD Report. (2016), World Investment Report - Investor nationality: policy changes, United Nations Publications. 